\title{
GENRE Campaign, Youth and Instagram
}

\author{
E Yuliawati', A Harlindawati² \\ 1,2Universitas Mercu Buana, Jakarta \\ 1.elly_yuliawati@mercubuana.ac.id, 255217110006@student.mercubuana.ac.id
}

\begin{abstract}
Early marriages still occur in Indonesia, causing various problems whose spectrum ranging from maternal mortality to child stunting. Adolescents as perpetrators of early marriages are targeted in the Generasi Berencana (wellplanned generation - shortened as GenRe) campaign conducted by the Indonesian National Population and Family Planning Agency (BKKBN). This study aims to analyze the communication strategy in the GenRe campaign through Instagram @bkkbnofficial. Use case studies as a method of parsing problems to find the solutions expected from GenRe campaign. Research results show that the campaign is carried out through the stages of content planning, implementation, namely by posting on instagram and evaluation conducted by BKKBN. There are three key messages in GenRe campaign namely avoiding premarital sex, maturing the age of marriage, and avoiding drugs. Based on these three keywords, the narrative "If Planned, Everything Is Easier" was chosen. There is a gap between Instagram@bkkbnofficial segmentation which reaches more young families while the GenRe campaign targets unmarried adolescents.
\end{abstract}

Keywords: Communication Strategy, Campaign, Planning Generation, Youth, Instagram

\section{INTRODUCTION}

The Central Statistics Agency (BPS) report on Population in 2018 released the percentage of early marriages in the country increased to 15.6 percent in 2018 , compared to the previous year 14.18 percent [1]. Indonesia is one of the highest countries in East Asia and the Pacific for the number of child marriage rates. Since 2008, child marriage rates have remained relatively stable at around 25 percent, no significant change. The results of the analysis reinforce the condition that child marriages in Indonesia are included in the emergency category. Early marriage does not only affect the health and population aspects, but also the economic burden on the country because health costs and living costs become greater. In addition, early marriage will bring about high school dropout rates, domestic violence, increased maternal mortality rates, increased stunting rates and low reproductive health. The results of the 2017 Indonesian Demographic and Health Survey (IDHS) showed the percentage of women aged 15-19 years who were already mothers or were pregnant with their first child in Indonesia by 7.1 percent, became mothers or were pregnant with their first child at the age of 16 by 2 percent, and the highest percentage being mothers or being pregnant with their first child at the age of 19 is 17 percent [2].

The National Population and Family Planning Agency (BKKBN) is present with the Generasi Berencana (well-planned generation-shortened as GenRe) Program as an effort to prevent child marriages from occurring. The aim of the GenRe campaign is to raise public awareness of the 
importance of maturing the marriage age [3]. The GenRe campaign targets adolescents, to prepare teens to plan families and mature marriage age.

GenRe is a program in PIK-KRR (Center for Information and Consultation on Adolescent Reproductive Health). PIK-KRR was established to assist youth in obtaining correct information about reproduction, both in terms of how to care for the reproductive organs and also make healthy reproduction in all aspects. This program introduces family planning to adolescents and keeps teenagers away from risky acts such as free sex, drug abuse, and HIV / AIDS infection [4]. Thus, the plans that have been prepared are not constrained by the three. PIK-KRR helps the government succeed in the family planning program for young people so that the government's goal to make the "Golden Generation" can be achieved [5].

But it is unfortunate that the majority of teenagers in Indonesia do not yet know the GenRe campaign. The results of the BKKBN RPJMN survey (2017) show that in the group of adolescents aged 15-19 years, as many as 30 percent have heard information about GenRe, less than the group of adolescents aged 20-24 years (32 percent). A similar pattern occurred in the percentage of male and female adolescents according to the region of residence, i.e. urban teenagers (32 percent) more had heard of GenRe than rural teenagers (29 percent). Based on the level of education, there is a tendency to the higher the level of education, the higher the percentage of teenagers who hear information about GenRe [6].

Table 1.1. Teenagers who have heard / seen / read information related to GenRe

\begin{tabular}{|c|c|c|c|c|}
\hline \multirow[t]{2}{*}{ Characteristic } & \multicolumn{3}{|c|}{$\begin{array}{c}\text { Teenagers who have heard/seen/reading GenRe } \\
\text { information }\end{array}$} & \multirow{2}{*}{$\begin{array}{l}\text { number of } \\
\text { teenagers }\end{array}$} \\
\hline & Yes & No & amount & \\
\hline MAN & 27 & 73 & 100 & 13,238 \\
\hline \multicolumn{5}{|l|}{ Age } \\
\hline $15-19$ & 26,7 & 73,3 & 100 & 8,572 \\
\hline $20-24$ & 27,5 & 72,5 & 100 & 4,666 \\
\hline \multicolumn{5}{|l|}{ Residence } \\
\hline urban & 28,9 & 71,1 & 100 & 5,425 \\
\hline rural & 25,6 & 74,4 & 100 & 7,813 \\
\hline \multicolumn{5}{|l|}{ Education } \\
\hline no school & 26,1 & 73,9 & 100 & 124 \\
\hline $\begin{array}{l}\text { Elementary } \\
\text { school }\end{array}$ & 18,3 & 81,7 & 100 & 1,293 \\
\hline Middle School & 23,5 & 76,5 & 100 & 3,236 \\
\hline High school & 28,3 & 71,7 & 100 & 7,311 \\
\hline College & 37,2 & 62,8 & 100 & 1,275 \\
\hline WOMAN & 34,2 & 65,8 & 100 & 10,64 \\
\hline \multicolumn{5}{|l|}{ Age } \\
\hline $15-19$ & 32,4 & 67,6 & 100 & 7,494 \\
\hline $20-24$ & 38,7 & 61,3 & 100 & 3,145 \\
\hline \multicolumn{5}{|l|}{ Residence } \\
\hline urban & 35,3 & 64,7 & 100 & 4,659 \\
\hline rural & 33,3 & 66,7 & 100 & 5,981 \\
\hline \multicolumn{5}{|l|}{ Education } \\
\hline no school & 25,1 & 74,9 & 100 & 66 \\
\hline
\end{tabular}




\begin{tabular}{lrrrr}
\hline $\begin{array}{l}\text { Elementary } \\
\text { school }\end{array}$ & 27,1 & 72,9 & 100 & 438 \\
\hline Middle School & 23,3 & 76,7 & 100 & 2,046 \\
\hline High school & 34,9 & 65,1 & 100 & 6,354 \\
\hline College & 46,7 & 53,3 & 100 & 1,736 \\
\hline $\begin{array}{l}\text { MAN \& } \\
\text { WOMAN }\end{array}$ & $\mathbf{3 0 , 2}$ & $\mathbf{6 9 , 8}$ & $\mathbf{1 0 0}$ & $\mathbf{2 3 , 8 7 8}$ \\
\hline Age & & & & 16,067 \\
\hline 15-19 & 29,3 & 70,7 & 100 & 7,811 \\
\hline 20-24 & 32 & 68 & 100 & 10,084 \\
\hline Residence & & & 100 & 13,794 \\
\hline rural & 31,9 & 68,1 & 100 & 190 \\
\hline urban & 28,9 & 71,1 & 100 & 1,731 \\
\hline Education & & & 100 & 5,282 \\
\hline no school & 25,7 & 74,3 & 100 & 13,665 \\
\hline $\begin{array}{l}\text { Elementary } \\
\text { school }\end{array}$ & 20,5 & 79,5 & 100 & 3,011 \\
\hline Middle School & 23,4 & 76,6 & 100 & KKBPK)
\end{tabular}

Source: 2018 Population, Family Planning and Family Development Program (SKAP - KKBPK) Performance and Accountability Survey [7]

The results of these studies also contributed to the success indicators of adolescent resilience development contained in the 2015-2019 BKKBN Strategic Plan, namely:

1. Reduction in Adolescent Fertility, measured through Age Specific Fertility Rates (ASFR) 15-19 years and Percentage of Adolescent Girls Age 15-19 years who are the First Mother and / or Pregnant Child;

2. Increased Mating Age, measured through the Median of First Marriage Age (UKP) for Women;

3. Increased Family Understanding of 8 Family Functions, measured by the Percentage of Families who have an Understanding and Awareness of 8 Family Functions.

Current conditions and expected conditions (2018 - 2019), as follows:

Table 1.2 Success Indicators for Youth Resilience Coaching

\begin{tabular}{llccc}
\hline & MEASURED ASPECTS & $\begin{array}{c}\text { ACHIEVE } \\
\text { MENTS } \\
2017\end{array}$ & $\begin{array}{c}\text { TARGET } \\
2018\end{array}$ & $\begin{array}{c}\text { TARGET } \\
2019\end{array}$ \\
\hline a. & ASFR 15-19 & 33 & 40 & 38 \\
\hline b. & $\begin{array}{l}\text { \% Of girls 15-19 years old who are mothers and first } \\
\text { child pregnant }\end{array}$ & 6,40 & 9,10 & 9,00 \\
\hline c. & UKP Median & 20,0 & 20,9 & 21 \\
\hline d. & Youth Knowledge Index about KRR* & 52,4 & 51 & 52 \\
\hline e. & \% Of Adolescents Who Access PIK Adolescents & 20,6 & 28 & 30 \\
\hline f. & $\begin{array}{l}\text { Participation of Families with Adolescents in Youth } \\
\text { Family Development Activities Groups ** }\end{array}$ & - & - & - \\
\hline g. & \% EFA of BKR members who have KB & 78.73 & 80 & 80 \\
\hline & & & & \\
\hline
\end{tabular}


(Source: December 2016 Field Control and PK 2015, Directorate of Reporting and Statistics, 2018)

Based on the conditions and targets in the BKKBN Strategic Plan, one of the efforts is to develop GenRe's communication strategy through new media and expand its reach to young people with disabilities, street children, prison residents, and working youth. The new media used in the framework of the GenRe campaign is to use Instagram @bkkbnofficial. The choice of Instagram platform is based on the high level of usage among teenagers in Indonesia.

Much research has been done on the use of social media, particularly highlighting the effectiveness of this media in disseminating information, making an impact on knowledge and changing attitudes and behavior. Teenagers with the speed of mastery of information and communication technology bring changes to their lives, including in the dissemination of knowledge about sexuality [8]. Social media has the advantage of sending messages at a low cost and large reach, but it is known about its feasibility as a tool to encourage changes in attitudes and behavior [9]. Management of social media content in marketing communication, the importance of Twitter to extract information, comments, and opinions submitted by consumers [10]. The use of cell phones as a medium of communication in adolescents aged 10-24 years in the dissemination of reproductive content so as to bring changes in knowledge and behavioral changes to increase knowledge about sexual and reproductive health [11]. The role of parents in providing education about adolescent sexual health, where cell phone technology provides innovation opportunities to reach most teenagers and their parents [12]

\section{RESEARCH METHOD}

This study uses a qualitative approach with the case study method [13], a method or strategy in research to uncover specific cases. Focusing on one particular object raised as a case to be studied in depth. The object of this research is the generation planning campaign through Instagram@bkkbnofficial. Data obtained through interviews and document review. The data obtained were then analyzed using Huberman interactive analysis model, which consisted of four stages, namely data collection, data reduction, data presentation and drawing conclusions [14].

\section{RESULTS AND DISCUSSION}

Campaign in principle is a process of communication activities of individuals or groups carried out in an institutionalized and aims to create a certain effect or impact. Rogers and Storey (1987) define campaigns as "a series of planned communication actions with the aim of creating a certain effect on a large number of audiences carried out sustainably over a certain period of time" [15].

Campaigns in the communication literature, consisting of the distribution of campaign models which generally focus on describing the stages of the campaign activity process. It can be said that there is no model that attempts to describe the campaign process based on the communication process. Because it displays the campaign model by describing the elements contained in it becomes important. The aim is to be able to understand the phenomenon of the campaign not only from the stage of its activities, but also from the interaction between the components contained therein. This study uses the Ostergaard Campaign model to see the implementation of the GenRe campaign that starts from planning, implementation and evaluation [16] 


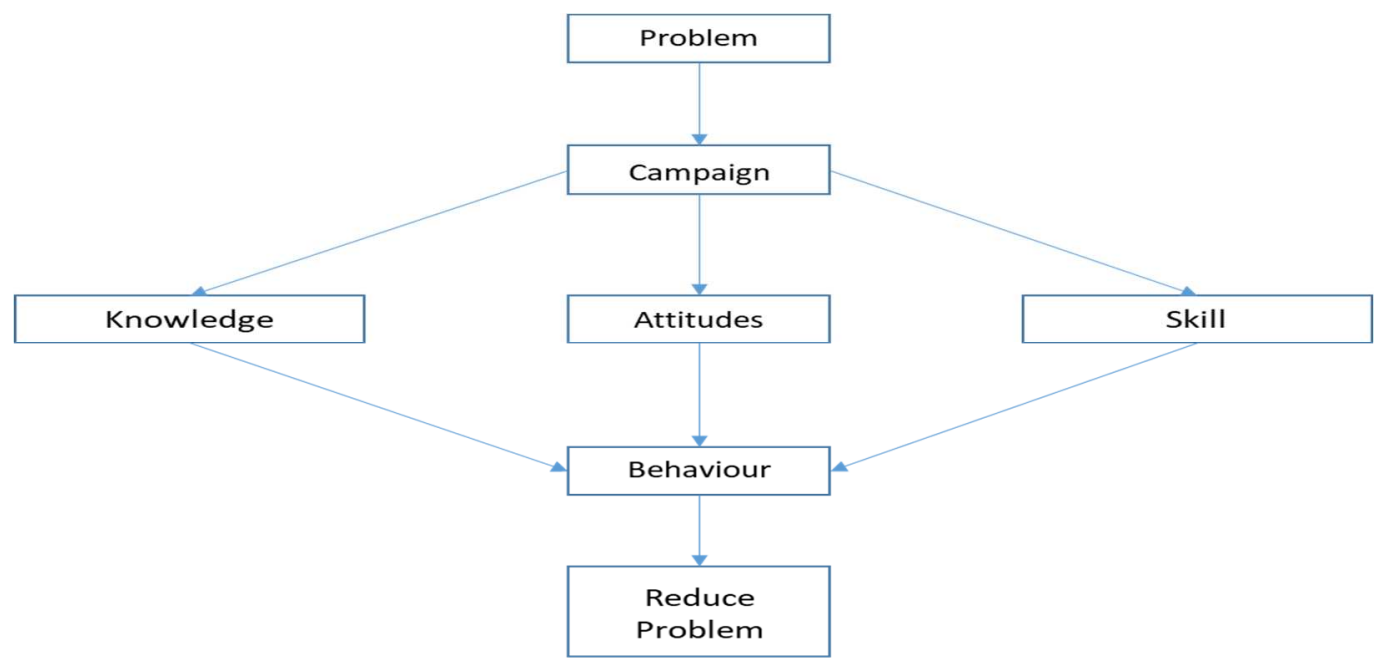

Figure 3.1. Ostergaard Leon Østergaard's

The first stage starts from clearly identifying the problem. The second stage is the management of the campaign that starts from the design, implementation to evaluation. At this stage of management the entire contents of the campaign program (campaign content) is directed to equip and influence aspects of the knowledge, attitudes and skills of the target audience.

\section{GenRe Campaign Through Instagram @bkkbnofficial}

The GenRe campaign based on its orientation is Ideologically or Cause Oriented Campaigns that are oriented towards specific social nature goals. Efforts to change include 3 (three) aspects, namely knowledge, attitudes, and behavior. The social media team provided knowledge about maturing marriage age by carrying the tagline "If Planned, Everything Is Easier" on each GenRe content posted on the @bkkbnoffcial account.

The first phase of the GenRe campaign activity is to provide information that inspires awareness and attracts the attention of adolescents and / or all netizens to find out about the GenRe and the message of maturing the age of marriage or young marriage. In the @bkkbnofficial account seen in posts, such as "Tips for Answering Questions When Marriage?" Or "Hard Code Praying to Pray Marriage". The post is a visual form that is equipped with narration on the caption, such as "What is clear, marriage is not fast, yes, plan carefully before you decide to get married. If it is planned, everything will be easier "or" What is clear, do not rush it. Think carefully and planned ". Here stands out the message "Planned", "Don't be in a hurry" becomes dominant in a GenRe campaign message made through Instagram @bkkbnoffcial. In the posting of February 2018 by borrowing the meme Dilan Milea there was content with the caption "Whoever marries or marries his child at school age, think again because it is heavy. I miss Milea to Dilan, "

The second stage of campaign content on Instagram should be directed towards a change in the realm of attitude, the aim of which is to bring sympathy, liking, concern or public support for issues of maturity at marriage. In the final stage, according to Ideologically or Cause Oriented Campaigns, the campaign is aimed at changing the behavior of the audience in a concrete and measurable way. This change is an ongoing and permanent action. Changes in the behavior of the GenRe campaign by the BKKBN were measured through the Program Performance and 
Accountability Survey (SKAP) conducted in 2018 by showing the results that the Government through the KKBPK Program appealed for adolescents to marry at an adequate age, ie over 21 years for women and above 25 years for men, so they can prepare themselves from the mental, economic, and health aspects.

In the Ostergaard campaign model, the steps taken in this GenRe campaign are carried out through 3 (three) steps, namely:

Identify factual problems. This is done by the BKKBN by conducting research on the Government Performance and Accountability Survey (SKAP), Inter-Census Population Survey Report (SUPAS), Statistics Indonesia (BPS), Demographic and Health Survey Indonesia (SDKI) which notes that early marriages are still widely conducted especially in rural areas in Indonesia.

Campaign management from design, implementation, and evaluation. The design step starts from determining the target segmentation of GenRe campaign audiences who are teenagers aged 10-24 years who are not married and the messages that will be delivered. The GenRe campaign was carried out based on the planning made by the BKKBN Social Media Team. Besides making reports on the implementation of GenRe campaigns on a regular basis in the form of digital Instagram reports. The final stage is the evaluation of the GenRe campaign carried out by the social media evaluation team conducted by the Directorate for Youth Resilience Development (DITHANREM).

The implementation of the GenRe campaign has become a reference for the GenRe Ambassador community in disseminating and educating adolescent marriage aged adults.

\section{Instagram}

Starting the review about Instagram@bkkbnofficial, the discussion starts from the components in the Instagram account. Username or Instagram account names are limited to only 30 characters which can be combined between letters, numbers, dots and underscores. The determination of the @bkkbnofficial account name consists of 13 letters that describe the account owner, the BKKBN government organization and the official signifying that the account is official. The profile listed in the account is a complete naming of BKKBN namely the Population and Family Planning Agency, the official website name and office address. The profile picture displays the official BKKBN logo with an illustration of a mother and two children holding hands. In Instagram Feed, the arrangement of photo posts is based on the momentum of existing BKKBN activities or content that is a program. Since the Instagram Feeds are being implemented, more and more users have been implementing photo upload settings and settings for their accounts to become a trend that must be followed. The @bkkbnofficial account creates an Instagram Feed with themes around programs carried out by BKKBN such as Great Parents and GenRe.

The audience as the communication target of the content on the Instagram account @ bkkbnofficial is actually more appropriate if it targets teenagers in the 15-24 age range who are followers on the account. This target is in line with the objectives of the Genre campaign, which is maturing the age of marriage, by reducing the number of early marriages committed by the age of the child, ie starting at the age of 10 years.

Instagram is a very large and active social media platform with users who want visual content that they can get. Because Instagram maximizes mobile applications, users can browse most of the time. If we see the type of interaction, namely like, comment, follow, share and direct message on the @bkkbnofficial account is done like the following example: 


\section{Most Liked}

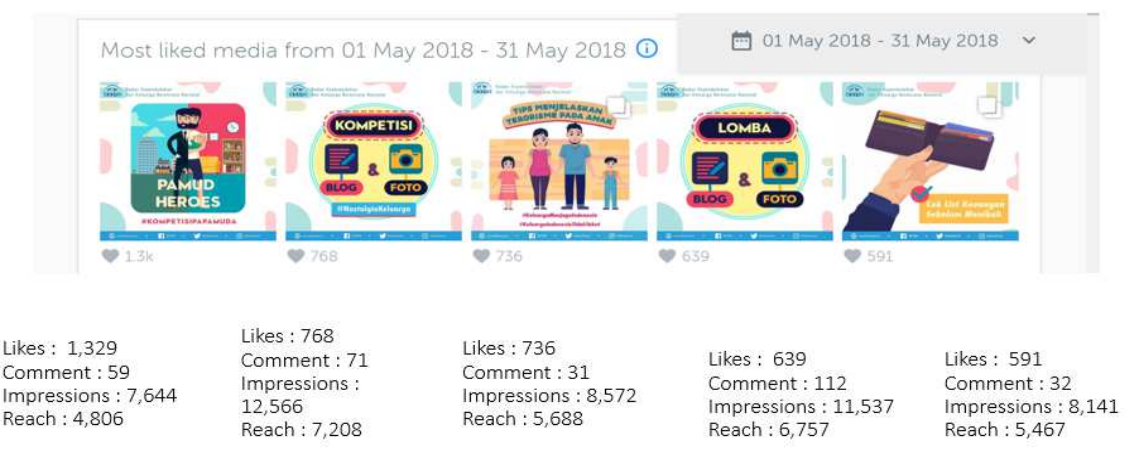

Figure 3.3. Number of Interactions on @bkkbnofficial accounts

Source: Instagram Management Report, Ditvokkom (2018)

The work process of the GenRe Social Media Team through Instagram @bkkbnofficial account can be described as follows:

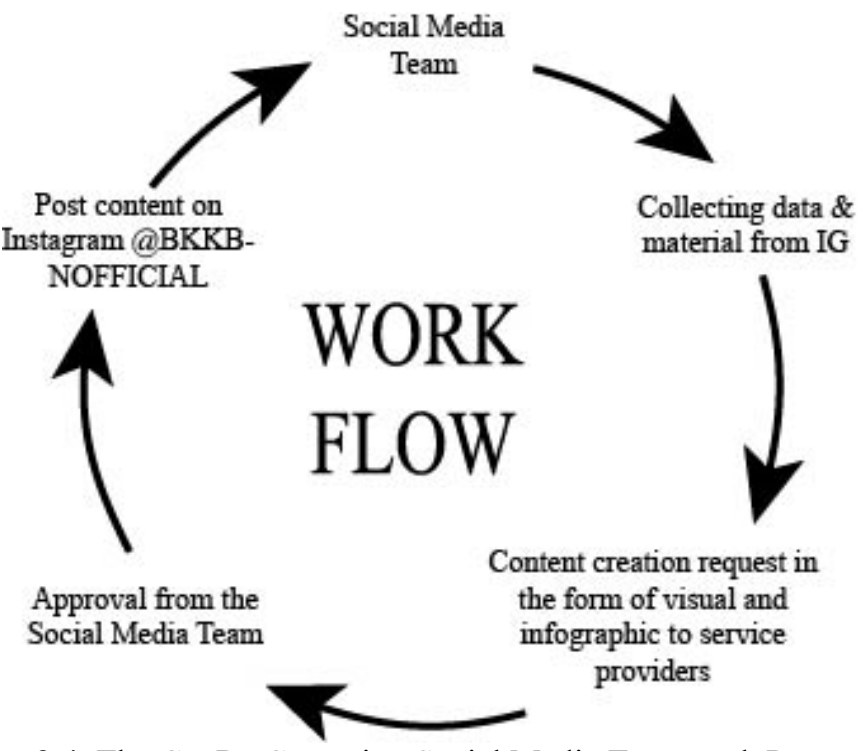

Figure 3.4. The GenRe Campaign Social Media Teamwork Process Source: Social Media Management report, Ditvokkom (2018)

\section{CONCLUSIONS}

The act of communication in the GenRe campaign through the Instagram account @ bkkbnofficial aims to give effect / impact to adolescents so that there will be a change in behavior from a minimal marriage plan to maturity of the marriage age. The key messages from this campaign are avoiding premarital sex, marriage age maturity, and avoiding drugs. So the narration that was built was "If Planned All Easier". 
This GenRe campaign was institutionalized by the BKKBN Social Media Team, starting with planning and editorial by the BKKBN Social Media Team so Instagram was chosen by creating an @bkkbnofficial account as the official BKKBN account. The naming of @ bkkbnofficial is considered less familiar to netizens. The target audience of account followers should be focused on the target recipients of the campaign message. The target audience for the GenRe campaign message is Indonesian teenagers aged 15-24 who are Generation Z. The aim is education on marriage age maturity for men at the age of 25 and women at age 21, to reduce the number of early marriages among teenagers Indonesia. Seen in the followers on Instagram account @ bkkbnofficial there are young families, impressed not right on target because the messages delivered to them using key messages are certainly different.

\section{REFERENCES}

[1] ANTARA News, "Lindungi Milenial dari Pernikahan Usia Dini."

[2] SDKI, Survey Demografi dan Kesehatan Indonesia. 2013.

[3] PIK Remaja-Genre, "Genre Indoneia," GenRe Indonesia. .

[4] E. Winarni, Kasmiyati, and H. Oesman, Survey Kependudukan, Keluarga Berencana, Kesehatan Reproduksi Remaja Dan Pembangunan Keluarga Di Kalangan Remaja Indonesia Tahun 2016, vol. 2, no. 2. 2018.

[5] BKKBN, "Apresiasi BKKBN kepada Remaja Melalui Pemilihan Duta GENRE," Badan Kependudukan Keluarga Berencana Nasional.

[6] BKKBN, Survei Kependudukan, Keluarga Berencana, Kesehatan Reproduksi Remaja dan Pembangunan Keluarga di Kalangan Remaja Indonesia Tahun 2017. 2017.

[7] P. Kb, “AKUNTABILITAS PROGRAM KKBPK ( SKAP ) Sasaran Renstra BKKBN 2018," no. November, 2018.

[8] S. L. Craig, L. B. McInroy, L. T. McCready, D. M. Di Cesare, and L. D. Pettaway, "Connecting Without Fear: Clinical Implications of the Consumption of Information and Communication Technologies by Sexual Minority Youth and Young Adults," Clin. Soc. Work J., vol. 43, no. 2, pp. 159-168, 2015.

[9] A. Gough et al., "Tweet for Behavior Change: Using Social Media for the Dissemination of Public Health Messages," JMIR Public Heal. Surveill., vol. 3, no. 1, p. e14, 2017.

[10] A. Nugroho and J. Sihite, "ASEAN tourism destination: A strategic plan," Eur. Res. Stud. J., vol. 21, no. 3, pp. 293-298, 2018.

[11] N. B. Ippoliti and K. L'Engle, "Meet us on the phone: Mobile phone programs for adolescent sexual and reproductive health in low-to-middle income countries," Reprod. Health, vol. 14, no. 1, pp. 1-8, 2017.

[12] V. Guilamo-Ramos, J. J. Lee, L. M. Kantor, D. S. Levine, S. Baum, and J. Johnsen, "Potential for Using Online and Mobile Education with Parents and Adolescents to Impact Sexual and Reproductive Health,” Prev. Sci., vol. 16, no. 1, pp. 53-60, 2014.

[13] R. K. Yin, Studi Kasus Desain dan Metode. Rajawali Pers, 2014.

[14] E. P. Irawan, "The Disclosure of Corporate Social Responsibility Motives: in the Socio Digi Leaders Program for Young Generation Indonesia,” Int. J. Curr. Res., vol. Vol. 10,Is, 2020.

[15] A. Venus, Manajemen Kampanye: Panduan Teoretis dan Praktis dalam Mengefektifkan Kampanye Komunikasi. Bandung: Simbiosa Rekatama Media, 2004. 
[16] N. Kurniasih, E. Rizal, Y. Winoto, N. Kurniawati, A. Sudirman, A. Hasibuan, A. Daengs GS, and K. Saddhono. "Online Media as a Movie Reference." In Journal of Physics: Conference Series, vol. 1114 no. 1, p. 012087. IOP Publishing, 2018. 